This article was published in Built Environment 32(2) (2006), pp. 124-136.

The definite version is available at:

http://www.atypon-link.com/ALEX/toc/benv/32/2

(C) Alexandrine Press http://www.alexandrinepress.co.uk/

\title{
Advantageous Fragmentation? Reimagining Metropolitan Governance and Spatial Planning in Rhine-Main
}

\author{
Michael Hoyler ${ }^{1}$, Tim Freytag ${ }^{2}$ and Christoph Mager $^{2}$ \\ ${ }^{1}$ Department of Geography, Loughborough University, Loughborough LE11 3TU, UK \\ e-mail: m.hoyler@lboro.ac.uk \\ ${ }^{2}$ Department of Geography, University of Heidelberg, Berliner Str. 48, 69120 Heidelberg, \\ Germany \\ e-mail: tim.freytag@geog.uni-heidelberg.de,christoph.mager@geog.uni-heidelberg.de
}

\begin{abstract}
This paper traces the latest round of debates about appropriate scales and scopes of government and governance in Rhine-Main - an economically highly integrated but politically, territorially and emotionally divided region. We identify a downscaling of political power from the regional to the municipal level, and an upscaling of informal networking and image building to an extended regional scale. These countertrends are signs of a more complex geographical rearrangement in municipal and institutional relations. The inherent contradictions in the rescaling and reimagining of Rhine-Main are evident in the Strategic Vision for Frankfurt/Rhein-Main 2020. Its new conceptualization of Rhine-Main postulates complementary polycentricity as a competitive asset but remains firmly grounded in an institutional territorial logic that contravenes its own economically-driven agenda.
\end{abstract}




\section{Introduction}

Rhine-Main presents something of a paradox among the six urban agglomerations first designated as 'European Metropolitan Regions' in German strategic spatial policy in the mid-1990s. As Germany's most globally connected city-region centred on an internationally highly visible Frankfurt (Freytag et al., 2006), it is arguably the agglomeration with the fuzziest external boundaries (Hoyler, 2005) and a comparatively weak regional identity (Blatter, 2005). Relations between Frankfurt as the dominant city in the region and its neighbouring municipalities have seen a long history of local competition and regional cooperation, resulting in changing institutional arrangements and a plethora of suggestions for metropolitan institutional reform (Scheller, 1998; Freund, 2003).

In this paper, we revisit the latest round of attempts to establish a new regime of metropolitan governance in the polycentric Rhine-Main urban region. First, we outline the national context of spatial policy and planning and discuss the recent strategic reorientation that moves away from the traditional focus on inter-regional equality and places greater emphasis on strengthening key metropolitan regions. Second, we show how political and economic actors in the administratively fragmented polycentric region have produced various contested and geographically divergent regionalizations of Rhine-Main. The underlying tensions and conflicts have been widely reported (Bördlein, 1999, 2000; Esser, 2001; Falger, 2001); here we explore how the functional diversity and multiplicity of perspectives in Rhine-Main have been reimagined as positive assets in the latest regional strategic policy documents and initiatives. We conclude with a critical evaluation of the state of metropolitan governance and spatial planning in Rhine-Main.

\section{The New Metropolitan Discourse in German Strategic Spatial Planning}

Spatial planning in postwar Germany has long been guided by the premise of balanced economic development to ensure equivalent living conditions throughout the national territory. Enshrined in the Spatial Planning Act of 1965, the idea of a 'spatial equilibrium at a national scale' (Brenner, 2000, p. 323), 
achieved through an even spacing of cities following Christaller's $(1966,1933)$ central place theory, dominated the planning discourse in Germany until the end of the 1980s. Since German reunification in 1990, and accelerated by national and European debates about ways to ensure competitiveness in a globalising economy, a 'gradual paradigm shift' (Blotevogel and Schmitt, 2005) has become visible in strategic spatial planning. Neil Brenner has argued that the underlying change in policy focus constitutes a transformation 'from a system of policies for alleviating uneven geographical development into a framework that actively intensifies it by promoting the continued recentralization of growth within specialized core urban regions' (Brenner, 2000, p. 332). Central to the new framework is the assumption that major metropolitan regions rather than individual cities or the national economy as a whole act as 'engines for societal, economic, social and cultural development' (BBR, 2005, p. 188) and therefore require specific attention (Ibid., p. 174). This view was first articulated prominently in two key policy documents by the Standing Conference of Federal and State Ministers Responsible for Spatial Planning (Ministerkonferenz für Raumordnung, MKRO), the Raumordnungspolitischer Orientierungsrahmen (1993) and the Raumordnungspolitischer Handlungsrahmen (1995). The latter identified the six urban agglomerations of Berlin/Brandenburg, Hamburg, Munich, Rhine-Main, Rhine-Ruhr and Stuttgart as 'European Metropolitan Regions' (EMR) with intensive international cross-border relations. This list was officially adopted in 1997, adding an EMR 'Sachsendreieck' ('Saxon triangle': Chemnitz, Dresden, Halle, Leipzig, Zwickau), and in 2005 EMR status was granted to Bremen/Oldenburg, Hanover-Brunswick-Göttingen, Nuremberg and Rhine-Neckar (MKRO, 2005).

The changing rhetoric evident in national planning guidelines and spatial visions has been accompanied by renewed debates about appropriate forms of metropolitan governance within the identified EMRs. The latest federal spatial planning report repeats earlier calls for the creation of a new level of strong regional governance in metropolitan areas to enhance international territorial competitiveness (BBR, 2005, p. 188), an argument that follows to some extent the dominant and often neoliberal narratives of globalization and interspatial competition that have informed much of Western European metropolitan policy discourse in recent years (Brenner, 2003, p. 18). However, the realization of 
effective planning and governance structures in specific agglomerations varies substantially between German metropolitan regions (Blatter, 2005; Fürst, 2005; Hesse, 2005), as the implementation of any such reforms depends on the cooperation of a multitude of political and economic actors within different institutional contexts. The diversity of forms of regional governance is in part due to contrasting historical trajectories and socio-economic structures of the metropolitan regions, and to the organization of the German federal system, built on the principles of subsidiarity and strong regional (Länder) and municipal autonomy. This finds expression in, for example, a multi-level planning system in which the federal state merely provides framework legislation and guidelines for regional planning (Kunzmann, 2001).

Each of the German Länder exerts authority over spatial planning in its territory and prepares regional planning policy guidelines, so-called development plans (Landesentwicklungsplan). The spatial planning legislation of the Länder divides their territories into planning regions (Planungsregionen), in each of which regional planning associations draw up a regional plan (Regionalplan). The municipalities of such a regional planning association participate in the development of the regional plan through a regional assembly. On the level of individual municipalities, spatial planning becomes concrete and legally binding through the implementation of land-use plans (Flächennutzungsplan) for a municipality or an association of municipalities (Regionaler Flächennutzungsplan). In general, the municipalities have exclusive planning rights over their territories, which means that the design of a land-use plan cannot be influenced directly by a higher planning authority, but is bound to adhere to their policy guidelines. This multi-level system of spatial planning, based on the principle of countervailing influence of the different tiers (Gegenstromprinzip) is complemented by spatially effective sectoral planning instigated by different federal and Länder ministries, so adding to the complexity of the planning process in Germany (figure 1).

While cooperation between major German cities and their neighbouring municipalities has a long history in terms of collaborative regional planning and issue-specific modes of cooperation through the formation of special purpose associations (for example, Zweckverband for public transport or waste management), the strong constitutionally safeguarded autonomy of local 
government has often hindered the development of comprehensive modes of metropolitan governance (Fürst, 2005). In addition, territorially fragmented regional identities and state competition in the federal system pose specific challenges for metropolitan regions that extend functionally across state boundaries, an issue that is particularly relevant in the case of Rhine-Main.

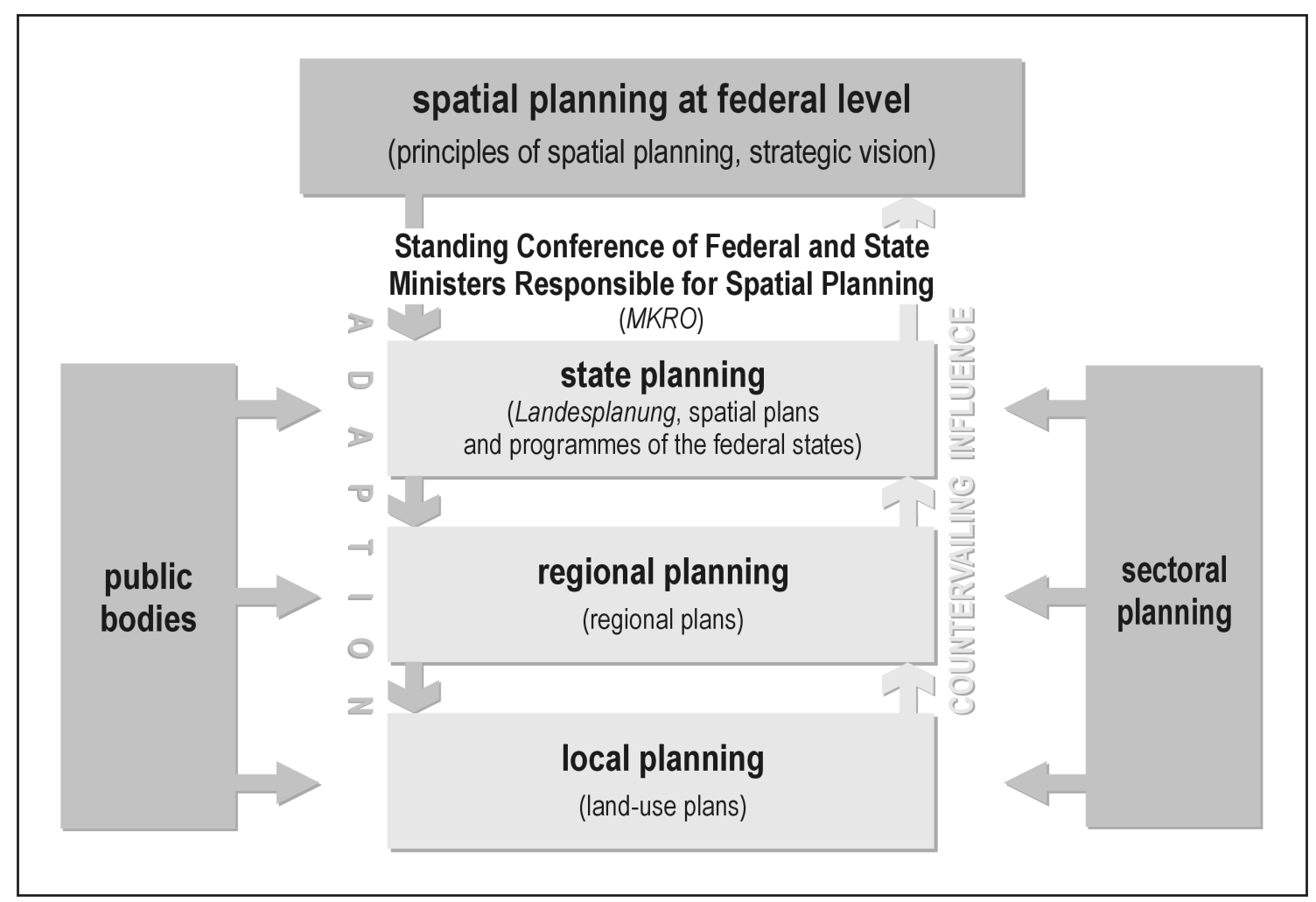

Figure 1. The organization of spatial planning in Germany. (Based on BBR, 2005, p. 219)

\section{Multiple Fragmentations: Spatial Planning and Metropolitan Governance in Rhine-Main}

As Germany's second largest urban agglomeration after Rhine-Ruhr, RhineMain is politically divided between the three states of Hesse (which covers most of the region), Rhineland-Palatinate and Bavaria. A distinctive regional consciousness is yet to emerge in an area in which allegiances are shaped by a long territorial history of political and administrative fragmentation and competitive localism (Bördlein and Schickhoff, 1998). Consequently, various regionalizations of 'Rhine-Main' exist - with Frankfurt always at the centre covering different parts of the wider region. The geographically most 
comprehensive definition of Rhine-Main as one of the eleven German EMRs includes an area of over $13,000 \mathrm{~km}^{2}$ with a population of 5.3 million inhabitants (Planungsverband, 2005) (figure 2).

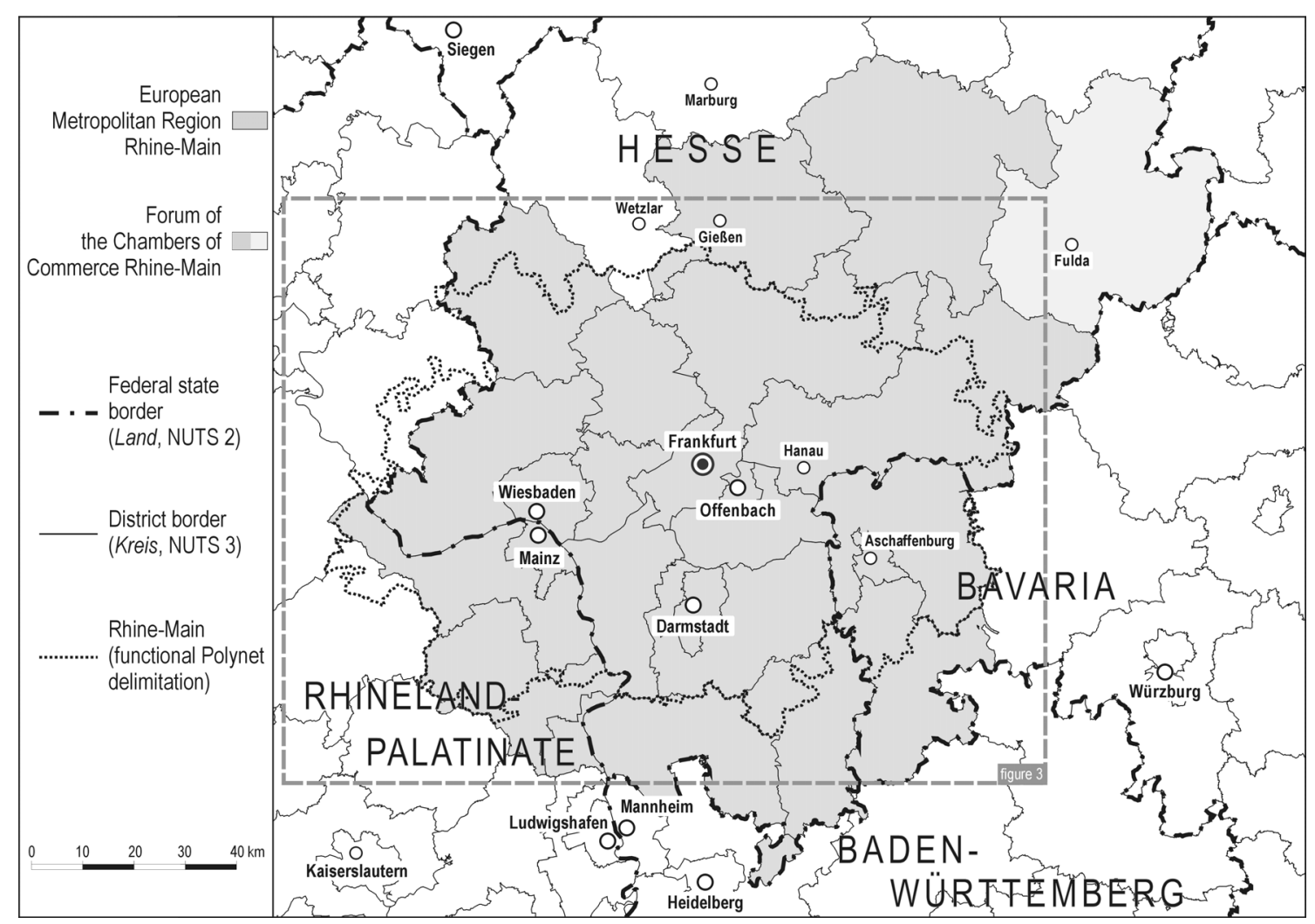

Figure 2. The metropolitan region Rhine-Main. (Based on Planungsverband, 2005; IHK)

Note: The EMR boundaries correspond with those used by the Planungsverband (2005) for the purpose of statistical monitoring; no official spatial delimitation exists in the documents at national level that first established EMRs.

This cross-border region coincides roughly with the delimitation chosen by economic actors in the region represented in the Forum of Chambers of Commerce and the Economic Development Board Frankfurt Rhine-Main. It contains a large fraction of rural districts, which are not included in functional delimitations based on evidence of daily commuting to the region's major urban centres: Frankfurt, Offenbach, Wiesbaden, Mainz, Darmstadt, Hanau and Aschaffenburg. A new definition of contiguous functional urban regions that form the 'mega-city region' Rhine-Main (INTERREG Illb project 'POLYNET': Fischer et al., 2005a, Freytag et al., 2006) encompasses an area of c. 8,000 $\mathrm{km}^{2}$ and 4.2 million inhabitants (figure 2). However, none of these cross-border conceptualizations of the region constitutes the metropolitan agglomeration 
formally as an administrative or politically unified area. Despite occasional initiatives at cross-border cooperation, debates about institutional reform have generally focused on the Hessian part of Rhine-Main and in particular on the relationship between the city of Frankfurt and its neighbouring municipalities.

New Institutions at the Heart of the Region

Current debates on spatial planning and metropolitan governance in RhineMain build on a long history of attempts to reform the institutional framework of city-regional relations for Frankfurt and its surrounding municipalities (Scheller, 1998; Freund, 2003). The latest round of institutional change was initiated in 1999 by the then newly elected conservative state government of Hesse through legislation for the Hessian part of the agglomeration, the Ballungsraumgesetz (BallrG, 2000). It created a new planning association for the Frankfurt conurbation in 2001, the Planungsverband Ballungsraum Frankfurt/Rhein-Main, as legal successor to the Umlandverband Frankfurt, a mandatory multipurpose association that had been established by a socialdemocratic government in 1975 for Frankfurt and forty-two neighbouring municipalities. Geographically enlarged but with reduced competencies, the new Planungsverband integrates - for the first time in Germany - the two levels of regional planning (jointly with the Regionalversammlung Südhessen) and land-use planning for seventy-five municipalities at the centre of the Hessian part of the Rhine-Main region (figure 3). A Rat der Region (Council of the Region) with representatives of the larger municipalities (over 50,000 inhabitants) and administrative districts (Landkreise) was established alongside the Planungsverband to coordinate inter-municipal cooperation (LanghagenRohrbach, 2004). Despite its extended geographical reach in terms of planning competencies, the new Planungsverband is only one of several planning authorities that cover the functionally defined Rhine-Main region. Crucially, there is no planning body in place that extends across state boundaries. The Länder Hesse, Rhineland-Palatinate and Bavaria all have their own planning policies and institutions for the respective parts of the Rhine-Main region and adjacent areas. 


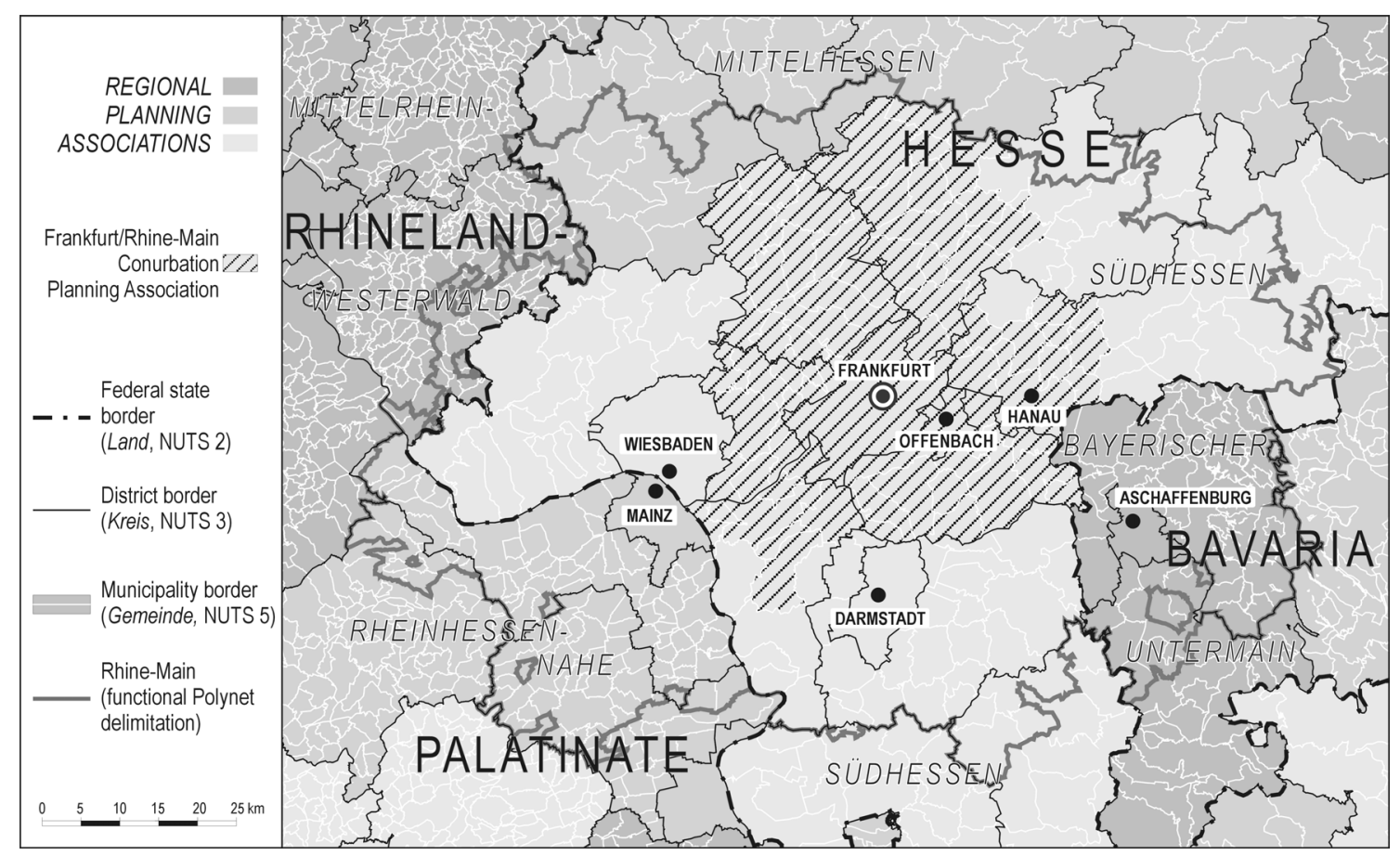

Figure 3. Regional planning associations in Rhine-Main.

Parallel to the establishment of the Rat der Region, a rival voluntary political framework for regional cooperation was initiated by the conservative mayor of Frankfurt in 2000, not least in an attempt to compensate for a lack of cooperation between the Planungsverband (dominated by Social Democrats and Greens) and the Rat der Region (conservative majority) (Blatter, 2005, p. 146). The Regionalkonferenz RheinMain, a regular meeting of directly elected mayors and heads of districts, covers an area equivalent to the much wider (cross-border) economic territorial definition of Rhine-Main (figure 2). It aims to stimulate municipal cooperation and to consult on sectoral issues such as economic development, culture, tourism and transport. However, in achieving these goals, the Regionalkonferenz faces difficulties that are similar to those of the Rat der Region, i.e. a weak institutionalization, lack of direct democratic legitimation, and political dissent and competition between municipalities that easily override cooperative aims (Blatter, 2005).

The restricted range of responsibilities of the politically-weakened new planning association leaves much of the cooperation between Frankfurt and its neighbours to voluntary inter-municipal arrangements which are, however, not limited to the administrative boundaries of the Ballungsraum. These have been slow to develop and critics fear a weakening rather than strengthening of regional cohesion as a consequence of the new legislation (Schultheis, 2003). 
Controversially, the state government of Hesse can force municipalities of the conurbation to collaborate in compulsory special purpose associations if they fail to enter into voluntary arrangements in any of the following tasks (BallrG, 2000): waste utilization and disposal; water supply; sewage disposal; regional sports and leisure facilities; cultural infrastructure; marketing and economic development; protection of green open spaces; regional transport planning and traffic management.

With varying geographical reach and membership, new voluntary intermunicipal organizations formed so far include the FrankfurtRheinMain $\mathrm{GmbH}$ International Marketing of the Region, a limited liability company for international locational marketing and branding of Rhine-Main, and the Kulturregion Rhein-Main-GmbH, founded in December 2005 by twenty municipalities and districts (inluding two Bavarian cities) to organize and present cultural events of regional and international importance. Further cooperation has been initiated for regional traffic management ('ivm $\mathrm{GmbH}$ ': Integriertes Verkehrsmanagement Region Frankfurt RheinMain) by several cities and districts and the states of Hesse and Rhineland-Palatinate (but without Bavarian participation). A number of Hessian cities and districts develop and link green open spaces in the region in a variety of projects under the heading Regionalpark RheinMain. The emerging picture is one of a downscaling of political responsibilities from the regional to the municipal level and the reluctant creation of purpose-specific cooperative arrangements with variable membership and only partly overlapping geographies.

Regional Initiatives in a Larger Rhine-Main

Since the 1990s, intensive and flexible networks between different political and economic actors have played a key role in initiating voluntary forms of cooperation in the wider region across state boundaries (figure 4). In 1991, the IHK-Forum Rhein-Main (Forum of the Chambers of Commerce) was created as a regional alliance that primarily addresses the needs and interests of small and mid size companies. Over 200 municipalities and several chambers of commerce, institutions of higher education and infrastructure companies 
cooperate in the Wirtschaftsförderung Region Frankfurt/Rhein-Main e.V. (Economic Development Board Frankfurt/Rhine-Main), founded in 1995 to attract investment and inform about available industrial real estate and office space in the region. The lack of a unified regional image was one of the incentives for major economic actors in Rhine-Main to establish the Wirtschaftsinitiative Frankfurt RheinMain in 1996, a promotional initiative of currently over 150 firms. The Wirtschaftsinitiative aims to foster a common regional identity, support prestigious and highly visible projects, and improve the public image of Rhine-Main to promote the region nationally and internationally. It is a major player in the development of a 'regional foreign policy' (Fichter, 2002, p. 315) for Rhine-Main. The Wirtschaftsinitiative was joined in 2003 by another initiative with similar aims, the Metropolitana. This organization had been founded one year earlier by five major international companies, the Hesse regional office of the Deutsche Bundesbank, the Wirtschaftsinitiative, the RhineMain public transport association and the Messe Frankfurt, to initiate innovative regional projects (Blatter, 2005, p. 147). Although the planned projects failed to be realized due to the lack of financial support by the firms involved in the Metropolitana (Ibid., p. 148), the strengthened Wirtschaftsinitiative has recently engaged in region-building 'from below' and initiated the first Regionalwerkstatt in 2004, a regional workshop that gathered different political and economic actors and the public to develop collectively ideas about the future of RhineMain. The initial meeting with several moderated thematic workshops found strong resonance in the region and attracted over 600 participants, but follow-up expert planning of specific projects has been slow and largely hidden from public view (Langhagen-Rohrbach and Fischer, 2005). It remains to be seen whether the second Regionalwerkstatt, scheduled for Spring 2006 to discuss the outcome of these project ideas, will achieve similar public involvement and enthusiasm as the first, and whether this will result in any concrete policy measures.

These recent attempts by public and private initatives to overcome territorial administrative boundaries and strengthen functional regionalizations and relations within various networks, have been strongly supported by many economic actors in Rhine-Main (Fischer et al., 2005b). Smaller regionally-based companies engage in this process either actively in specific projects or as 
members of local and regional business organizations. Major international firms play an important role in initiating and supporting internationally visible Leuchtturmprojekte and image campaigns, both out of self-interest and as part of their corporate citizenship strategies. The idea of a functionally integrated metropolitan region Rhine-Main corresponds with the perspective and experience of economic decision-makers who operate in flexible spaces, structured by cross-border flows and networked business relations (Ibid.). However, one of the key questions remains to what extent the often short-lived projects and the primarily economic perspective legitimately represent the wider population in Rhine-Main. Participatory processes such as the Regionalwerkstatt may prove to develop a more inclusive perspective of a larger Rhine-Main.

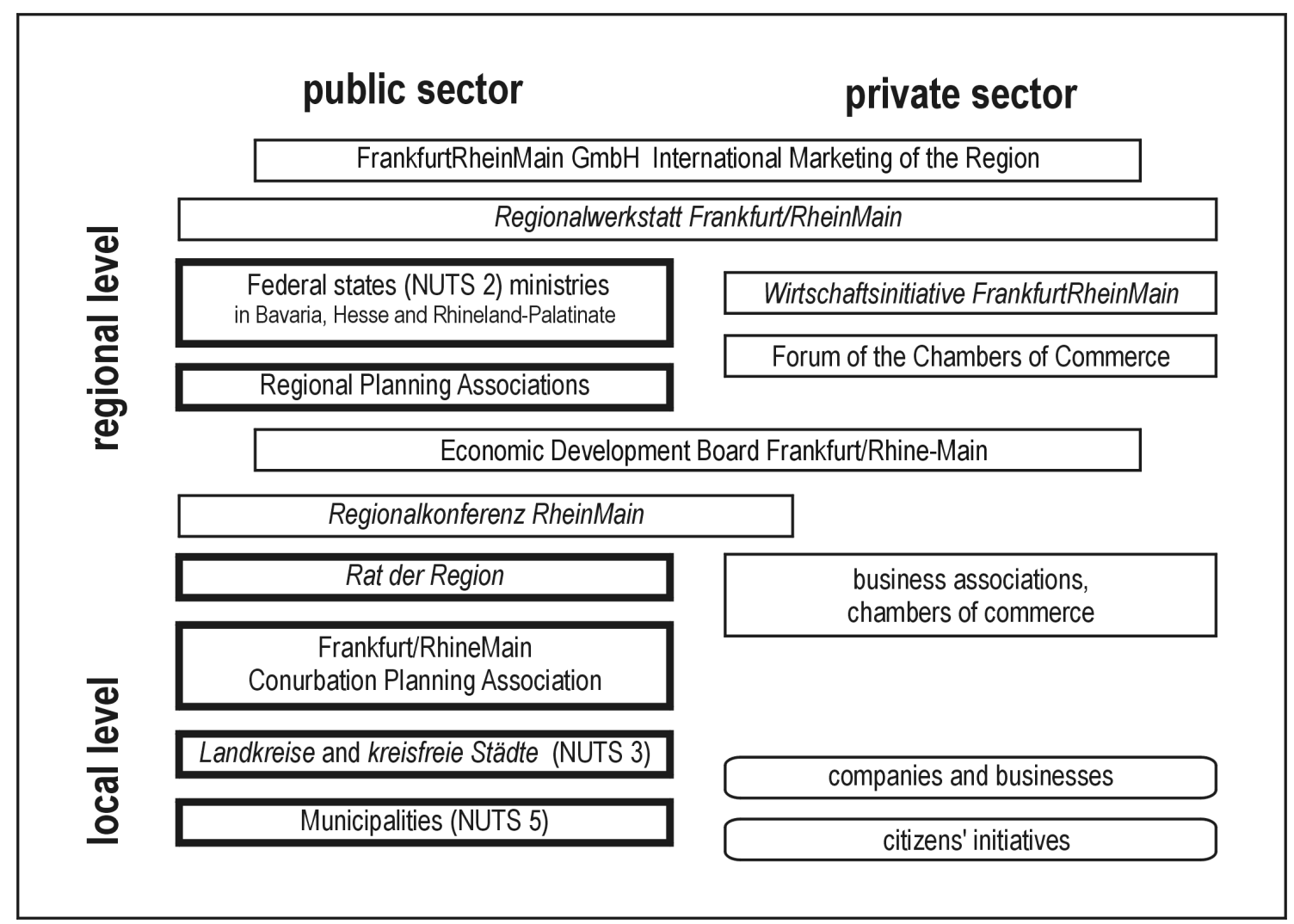

Figure 4. Metropolitan governance in Rhine-Main: public and private actors and institutions. (Based on Hesse, 2005, p. 36; Langhagen-Rohrbach and Fischer, 2005, p. 78) 


\section{Polycentric Perspectives? The Strategic Vision 'Frankfurt/Rhein-Main 2020'}

While the initial ideas of the Regionalwerkstatt continue to be reworked, a key policy document, the 'Strategic Vision for the Regional Land Use Plan and for the Regionalplan Südhessen', was published in 2005 for the area of the Ballungsraum and the wider spatial planning region Südhessen (Planungsverband and Regierungspräsidium, 2005). Its remit extends further south than the usual delimitation of Rhine-Main but, due to restricted planning competencies, is limited to the state of Hesse, although wider functional relations across state boundaries are (briefly) acknowledged. As yet another initiative in which key public and private institutional actors in Rhine-Main have come together, the Strategic Vision outlines aims for the development of a major part of the region over the coming 15 years for a wide range of themes. As a collective 'ideal vision' of those engaged in regional institution-building and networking, it provides both a key reference point for the future development of Rhine-Main but at the same time reveals the inherent tensions between the territorial logic of spatial planning and the economically driven discourse of trans-border connections.

Developing a Vision

As visionary guideline for the legally binding land-use plans that are currently being developed for Südhessen and the Frankfurt conurbation, the Strategic Vision is the outcome of a cooperation between the two institutions responsible for spatial planning in the region, the Planungsverband Ballungsraum Frankfurt/Rhein-Main and the Regierungspräsidium Darmstadt. It is by no means a vision imposed by planning authorities alone, but was drafted after extensive consultation of about 280 regional actors drawn from the fields of politics, business, culture, municipal administration and higher education. Although the wider public was invited to participate via an internet platform, the response (109 active participants; Salz et al., 2004, p. 7) was less extensive than participation in the first phase of the Regionalwerkstatt; an example for the 
often innovative but not always coordinated regional initiatives in Rhine-Main (Langhagen-Rohrbach and Fischer, 2005, p. 79). The Strategic Vision was approved in 2004 as a guideline for future spatial planning in the region by the decision-making body of the Planungsverband and by the Regional Assembly Südhessen, which represents cities and districts in Südhessen.

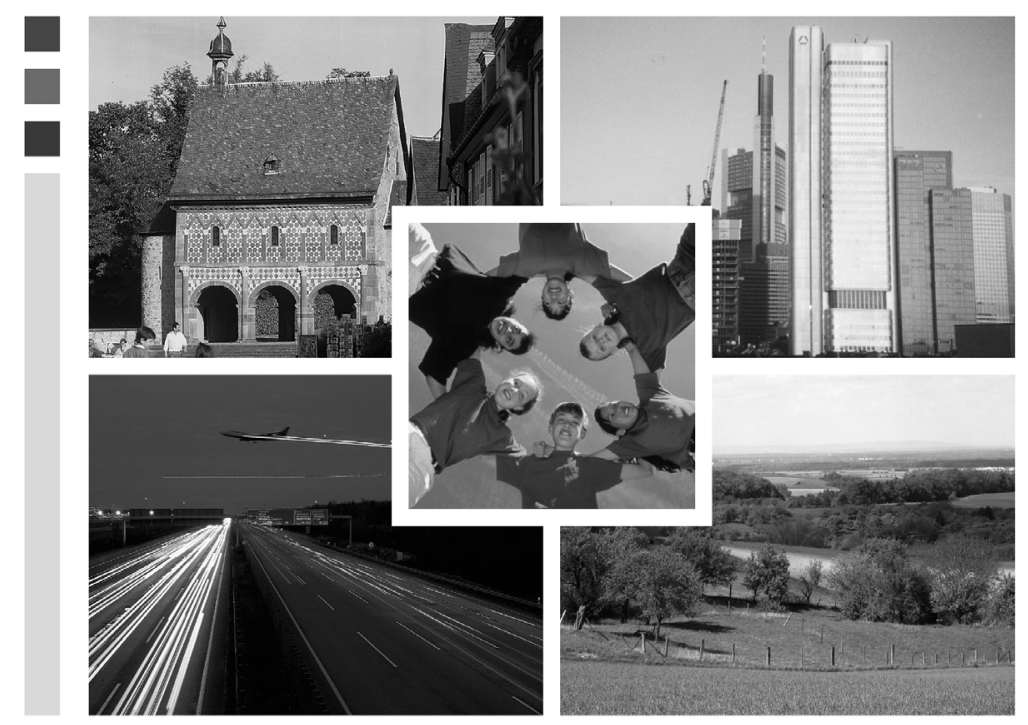

\section{Frankfurt/Rhein-Main 2020 - the European metropolitan region}

Strategic Vision for the Regional Land Use Plan and for the Regionalplan Südhessen

Figure 5. English version of the Strategic Vision Frankfurt/Rhein-Main 2020. (Source: Planungsverband Ballungsraum Frankfurt/Rhein-Main and Regierungspräsidium Darmstadt, 2005) 
Central to the Strategic Vision is a discourse that promotes diversity and functional urban specialization in Rhine-Main as positive assets rather than barriers to communication and regional economic success (box 1). Multiplicity, complementarity and synergy are the buzz-words in a document that explicitly links economic competitiveness to the region's polycentric urban structure. The Strategic Vision acknowledges the functional complementarity of the various urban centres in the region - Frankfurt as 'centre of the region's economic and cultural life', Darmstadt as 'major research centre', Hanau as 'city of materials science', Offenbach as 'city of design', Wiesbaden as 'capital of the Land of Hessen' - and explicitly encourages municipalities to develop and strengthen their individual economic profiles in order to engage in 'productive competition' (Planungsverband and Regierungspräsidium, 2005, p. 11). The balance between competition and cooperation is seen as potentially beneficial to the region. Furthermore, the document highlights potential synergies through densely networked cities on different scales - both within the region and within wider European transnational networks. Given this rhetoric, the major irony of the document is the lack of a truly polycentric vision of Rhine-Main itself - the functionally linked but administratively separate cities of Mainz (RhinelandPalatinate) and Aschaffenburg (Bavaria) (Freytag et al., 2006, Fischer et al., 2005c) do not feature at all in a Strategic Vision that cannot escape its institutional territorial logic. While the Strategic Vision has adopted the discourse of global economic competition, the hands of its authors are institutionally tied by administrative boundaries that cut through the functional relations highlighted as key assets in the document.

In the absence of any definite statements on controversial issues in the region, such as airport expansion, identification of new industrial estates or integration of immigrant populations, it may be argued that the Strategic Vision is little more than an exercise in regional branding and boosterism, driven by an entrepreneurial discourse that has shaped its objectives. The simultaneous publication of both a German and an English version would seem to support the contention that this is primarily a document directed at an outside audience (figure 5). Such a view, however, underestimates the potentially cohesive value 
of an agreed regional vision in a traditionally divided region. The Strategic Vision is as much an attempt to bring together the often conflicting interests of regional elites - at least in the Hessian core of the region - as it is an attempt to present a coherent image to the outside world.

The particular strength of the Frankfurt/Rhine-Main region lies in the multiplicity of towns and municipalities... We intend to make use of this extraordinary quality in a metropolitan region by developing the various different strengths and potentials of the different towns and rural areas. We intend to secure the development of the urban centres, make optimal use of existing settlement areas, and, in specific cases, develop new areas for settlement. (p. 5)

The Frankfurt/Rhein-Main region needs to take on two major tasks. Firstly, it must present an image of itself to the world, creating a profile as a region with good educational facilities, attractive jobs, and a high quality of life - a region where people enjoy living and working. Secondly, the individual municipalities must, as part of their role in managing their own affairs, develop their individual strengths - without neglecting positive synergy effects with other towns and municipalities. Thus they can develop productive competition which will benefit the region, and play their part in creating the region's profile. (p. 11)

No man is an island - and today, the world is more closely interlinked than ever. This is both a challenge and an opportunity. For this reason, communication and the exchange of information form the basis of a successful region. One individual body or municipality cannot, alone, meet the variety of demands made of it. But the region, as a cooperation between a large number of different agents, can ensure that everyone profits from, and participates in, the overall network.

This competitive advantage is of benefit both to each individual and to the region as a whole. We intend to work together more closely with other metropolitan regions on a national and European level in order to increase efficiency and to jointly represent our interests in Europe...

The Frankfurt/Rhein-Main region is already one of the most important nodal points in the financial, transport and data exchange networks, both nationally and internationally. We intend to secure this position, and to develop it further...

The settlement structure of our region can be seen as a networked urban landscape in which the different municipalities, with their differing strengths, complement one another but are, at the same time, dependent on each other. (p. 12)

Box 1. Polycentricity as competitive asset: Rhine-Main in the Strategic Vision 2020. (Source: Planungsverband and Regierungspräsidium, 2005) 


\section{Conclusion}

This article has explored the effects of the most recent round of institutional reform at the heart of the Rhine-Main region for metropolitan governance and spatial planning. Despite its high international visibility, the region remains internally fragmented both politically and administratively and lacks a clear regional identity. Shifting constellations of public and private institutional actors have produced a multitude of 'Rhine-Mains': a narrowly circumscribed 'Ballungsraum Frankfurt/Rhein-Main', the 'Frankfurt/Rhein-Main' of the Strategic Vision that encompasses southern Hesse, an economic vision of 'Frankfurt/Rhein-Main' that transcends state boundaries, a vague and spatially unfixed 'European Metropolitan Region', and various functionally defined RhineMains, based for example on commuting and employment patterns or on taskspecific inter-municipal cooperations.

The latest institutional change in Rhine-Main has weakened rather than strengthened regional institutions and placed responsibility for regional cooperation firmly in the hands of the politically autonomous municipalities. Decentralization of power and a reliance on voluntary arrangements characterize this institutional framework, leading to geographically variable and functionally specialized cooperations. Beyond the Frankfurt conurbation and Southern Hesse, the region remains fundamentally divided along political and planning responsibilities that stop at Länder boundaries. It comes as no surprise therefore that both economic and political elites have focused their attention on voluntary and informal initiatives to market the region internationally and promote an image of a diverse, but complementary polycentric region. The websites of the Wirtschaftsinitiative and the FrankfurtRheinMain $\mathrm{GmbH}$ International Marketing of the Region both prominently proclaim unity among the cities that constitute the wider cross-border region: 'United Cities of FrankfurtRheinMain' (http://www.wifrm.de/) and 'FrankfurtRhineMain - the cities of RhineMain united' (http://www.frm-united.com/). As such an economicallydriven view of unity runs counter to past political experiences in the region (Freund, 2003), it remains to be seen if forms of 'creative governance' (Kunzmann, 2004), that imaginatively rethink regional political and 
administrative cooperation in a cross-boundary Rhine-Main, can be more firmly established.

\section{References}

BallrG (Ballungsraumgesetz) (2000) Gesetz zur Stärkung der kommunalen Zusammenarbeit und Planung in der Region Rhein-Main vom 19. Dezember 2000. Gesetz- und Verordnungsblatt für das Land Hessen, I(29).

BBR (Bundesamt für Bauwesen und Raumordnung) (2005) Raumordnungsbericht 2005. Bonn: BBR.

Blatter, J. (2005) Metropolitan Governance in Deutschland: Normative, utilitaristische, kommunikative und dramaturgische Steuerungsansätze. Swiss Political Science Review, 11(1), pp. 119-155.

Blotevogel, H.H. and Schmitt, P. (2005) The 'European Metropolitan Region Rhine-Ruhr' in the context of the gradual paradigm shift in strategic spatial planning in Germany, in Feldhoff, T. and Flüchter, W. (eds.) Shaping the Future of Metropolitan Regions in Japan and Germany: Governance, Institutions and Place in New Context. Duisburg: Universität Duisburg-Essen, pp. 13-26.

Bördlein, R. (1999) 'Region Rhein-Main': Rahmenbedingungen und Konzepte im Institutionalisierungsprozess einer Region. DISP, nos. 136/137, pp. 63-69.

Bördlein, R. (2000) Regionalreform Rhein-Main: Kommunikation und Kooperation oder Konfusion? Standort - Zeitschrift für Angewandte Geographie, 24(2), pp. 11-17.

Bördlein, R. and Schickhoff, I. (1998) Der Rhein-Main-Raum, in Kulke, E. (ed.) Wirtschaftsgeographie Deutschlands. Gotha: Klett-Perthes, pp. 465-495. 
Brenner, N. (2000) Building 'Euro-Regions': Locational politics and the political geography of neoliberalism in post-unification Germany. European Urban and Regional Studies, 7(4), pp. 319-345.

Brenner, N. (2003) Standortpolitik, state rescaling and the new metropolitan governance in Western Europe. DISP, no. 152, pp. 15-25.

Christaller, W. (1966, 1933) Central Places in Southern Germany. Translated by C.W. Baskin. Englewood Cliffs, NJ: Prentice-Hall.

Esser, J. (2001) Die politische Konstruktion regionaler Kooperation: Der Fall Regionalreform Rhein-Main. Comparativ - Leipziger Beiträge zur Universalgeschichte und vergleichenden Gesellschaftsforschung, 11(3), pp. 6476.

Falger, M. (2001) Regionalreform - zwischen Hierarchie und Netzwerk, in Esser, J. and Schamp, E.W. (eds.) Metropolitane Region in der Vernetzung: der Fall Frankfurt / Rhein-Main. Frankfurt am Main: Campus, pp. 215-244.

Fichter, H. (2002) Regionale Handlungsfähigkeit im europäischen Wettbewerb: spezifische Ausprägungen regionaler governance-Formen am Beispiel dreier deutscher Metropolregionen. Informationen zur Raumentwicklung, nos. 6/7, pp. 313-324.

Fischer, C., Freytag, T., Hoyler, M. and Mager, C. (2005a) Rhine-Main: Commuting and the Definition of Functional Urban Regions (POLYNET Action 1.1). London: Institute of Community Studies/The Young Foundation \& Polynet Partners.

Fischer, C., Freytag, T., Hoyler, M. and Mager, C. (2005b) Rhine-Main: Qualitative Analysis of Service Business Connections (POLYNET Action 2.1). London: Institute of Community Studies/The Young Foundation \& Polynet Partners. 
Fischer, C., Freytag, T., Hoyler, M. and Mager, C. (2005c) Rhein-Main als polyzentrische Metropolregion: zur Geographie der Standortnetze von wissensintensiven Dienstleistungsunternehmen. Informationen zur Raumentwicklung, no. 7, pp. 439-446.

Freund, B. (2003) The Frankfurt Rhine-Main region, in Salet, W., Thornley, A. and Kreukels, A. (eds.) Metropolitan Governance and Spatial Planning: Comparative Case Studies of European City-Regions. London: Spon, pp. 125144.

Freytag, T., Hoyler, M., Mager, C. and Fischer, C. (2006) Rhine-Main: making polycentricity work? In: Hall, P. and Pain, K. (eds.) The Polycentric Metropolis: Learning from Mega-City Regions in Europe. London: Earthscan.

Fürst, D. (2005) Metropolitan governance in Germany, in Heinelt, H. and Kübler, D. (eds.) Metropolitan Governance: Capacity, Democracy and the Dynamics of Place. London: Routledge, pp. 151-168.

Hesse, J.J. (2005) Modelle der Stadt-Umland-Organisation in der Bundesrepublik Deutschland. Vergleichsanalyse und Schlussfolgerungen für den Raum Saarbrücken. Berlin: Internationales Institut für Staats- und Europawissenschaften.

Hoyler, M. (2005) Where does Frankfurt end? Paper presented at the GLA Economics Seminar 'Measuring World Cities', London, 22 September 2005, http://www.london.gov.uk/mayor/economic_unit/world_cities.jsp (06/01/2006).

Kunzmann, K.R. (2001) State planning: a German success story? International Planning Studies, 6(2), pp. 153-166.

Kunzmann, K.R. (2004) An agenda for creative governance in city regions. DISP, no. 158, pp. 5-10. 
Langhagen-Rohrbach, C. (2004) Aktuelle Regionalisierungsprozesse in der Region Rhein-Main. Raumforschung und Raumordnung, 62(1), pp. 58-66.

Langhagen-Rohrbach, C. and Fischer, R. (2005) Region als Prozeß? Regionalwerkstatt FrankfurtRheinMain. Standort - Zeitschrift für Angewandte Geographie, 29(2), pp. 76-80.

MKRO (2005) Beschluss der 32. Ministerkonferenz für Raumordnung am 28.04.2005 in Berlin.

Planungsverband Ballungsraum Frankfurt/Rhein-Main (2005) Regionales Monitoring 2005. Zahlen und Karten zur Metropolregion Frankfurt/Rhein-Main. Frankfurt.

Planungsverband Ballungsraum Frankfurt/Rhein-Main and Regierungspräsidium Darmstadt (2005) Frankfurt/Rhein-Main 2020 - the European metropolitan region. Strategic Vision for the Regional Land Use Plan and for the Regionalplan Südhessen. Frankfurt, Darmstadt.

Salz, S., Märker, O. and Michaelis, S. (2004) Auswertung und Ergebnissicherung des Internet-Forums 'www.planung-verbindet.de'. St. Augustin: Fraunhofer Institut Autonome Intelligente Systeme (AIS).

Scheller, J.P. (1998) Rhein-Main: eine Region auf dem Weg zur politischen Existenz. Frankfurt am Main: Institut für Kulturgeographie, Stadt- und Regionalforschung der Johann-Wolfgang-Goethe-Universität.

Schultheis, J. (2003) Zwischen Heimatgefühl und Weltstadtanspruch: die Region Frankfurt/Rhein-Main. DISP, no. 152, pp. 80-86. 


\section{Acknowledgements}

The research for this paper was undertaken as part of the INTERREG IIIb North West Europe project 'POLYNET - Sustainable Management of European Polycentric Mega-City Regions'. We acknowledge funding by the European Union, the Ministry of Science, Research and the Arts of the State of BadenWürttemberg, and the University of Heidelberg. We would like to thank all interviewees and focus group participants from public and private organizations who generously shared their knowledge with us, and Stefan Berwing for valuable research assistance during POLYNET Action 3.1. 